\title{
Germplasm of Hevea brasiliensis in Nigeria
}

\author{
Omokhafe K. O.*, Aghughu 0. and Imoren E. A. \\ Rubber Research Institute of Nigeria, PMB 1049, Benin City, Nigeria.
}

Publication history: Received on 25 September 2017; Revised on 03 November 2017; Accepted on 09 November 2017

https://doi.org/10.30574/gscbps.2017.1.2.0025

\begin{abstract}
New countries adopting the cultivation of the rubber tree have the challenge of sourcing for germplasm of Hevea brasiliensis. In addition, breeding for adverse weather occasioned by climate change will require robust germplasm for genetic improvement. The objective of this study therefore was to provide inventory of available germplasm of Hevea brasiliensis in Nigeria. Census of germplasm of $H$. brasiliensis in Rubber Research Institute of Nigeria was conducted, and data was subjected to t-test. There was percentage representation of the various types of germplasm. There were seventy six genotypes represented by the highest number of 50 from Malaysia, 10 from Indonesia, 6 from Nigeria, 4 from Sri Lanka, 3 from Brazil, 2 from Liberia and one of Vietnam origin. The germplasm consisted of $4 \%$ of genotypes of unknown pedigree, $20 \%$ of primary clones and $76 \%$ of improved clones. This number, origin and type of germplasm suggest potential for utilization of Hevea germplasm in Nigeria for genetic improvement. Possible exchange under suitable bilateral or multilateral arrangement is hereby recommended.
\end{abstract}

Keywords: Hevea brasiliensis; Germplasm; Budwood/source bush garden

\section{Introduction}

The plant Hevea brasiliensis Muell. Arg. is valued for the natural rubber obtained from the tree. Among other crops producing natural rubber called latex are Parthenium spp., Funtumia spp., Ficus spp., Manihot spp. etc [1]. The advantage of $H$. brasiliensis is the ability to produce latex with repeated cuttings at close and regular frequency. The scientific interest in natural rubber from H. brasiliensis dates back to 1736 and in 1876 there was seed collection from its place of origin, which is the Amazon basin in South America [2]. The first use of latex from H. brasiliensis was the eraser to clean pencil writing. It is believed that the name rubber is closely associated with this early discovery to rub off pencil writing. The boost to the interest in H. brasiliensis was the discovery of vulcanization in 1839 leading to the production of tyre and tubes using vulcanized natural rubber [3]. Till date, the production of automobile tyres and tubes, rubber bearings and bushings requires high input of natural rubber. Natural rubber has the advantage of heat resistance over synthetic rubber, hence the relevance of natural rubber in production of heat tolerant items such as tyre, tube, bushings and bearings.

With the discovery of the importance of natural rubber in the nineteenth century, several countries in Asia and Africa embarked on germplasm collection, evaluation, recommendation of improved planting materials and plantation development. Among these countries were Malaysia, Thailand, India, Vietnam in Asia and Liberia, Cote d'Ivoire, Nigeria, Cameroun, Democratic Republic of Congo in Africa. In recent times, Ghana in Africa and Myanmar in Asia have embarked on research and development of $H$. brasiliensis and they will source for Hevea germplasm. The International Rubber Research and Development Board is encouraging member countries to exchange genetic materials of $H$. brasiliensis [4]. In addition, the concerns of environmental degradation occasioned by climate change require an environment-friendly long duration crop such as the rubber tree. In this regard, extensive germplasm collection,

\footnotetext{
${ }^{*}$ Corresponding author

E-mail address: kenomokhafe2001@yahoo.com
}

Copyright (C) 2017 Author(s) retain the copyright of this article. This article is published under the terms of the Creative Commons Attribution Liscense 4.0. 
conservation and evaluation will be required to develop new clones adapted to adverse weather conditions [5]. The knowledge of available genetic materials of $\mathrm{H}$. brasiliensis in the various countries to facilitate exchange is necessary in order to address these challenges. The objective of this paper therefore was to provide update on available germplasm of $H$. brasiliensis in Nigeria.

\section{Material and methods}

The Department of Crop Improvement and Management of the Rubber Research Institute of Nigeria (RRIN) carried out census of germplasm available in source bush gardens of the institute. The available clones in the source bush gardens at RRIN, Iyanomo, Nigeria were documented by simple census and classified based on the country of origin. The location coordinates were $6^{\circ} 00^{\prime}-6^{\circ} 15^{\prime} \mathrm{N}$ and $5^{\circ} 30^{\prime}-5^{\circ} 45^{\prime} \mathrm{E}$ as described by Begho et al. [6]. There was mean separation using t-test to determine the relative abundance of country clones in the source bush gardens. Percentage of status of the clones was calculated.

\section{Results}

The Rubber Research Institute of Nigeria (RRIN) has the national mandate for research and development of all latex producing plants in Nigeria including Hevea brasiliensis [7]. It is a member of the International Rubber Research and Development Board [4]. Germplasm collection in RRIN commenced in the 1960s till the 1980s and there is effort to benefit from the on-going multilateral clone exchange coordinated by the IRRDB [8]. From the 1960s till the 1980s, germplasm collected included clones of the following countries: Malaysia, Indonesia, Sri Lanka, Vietnam, Brazil and Liberia. Since the 1960s, RRIN embarked on genetic improvement of $H$. brasiliensis leading to the development of two sets of improved clones called NIG 800 series and NIG 900 series [9]. The RRIN therefore has germplasm of $H$. brasiliensis consisting of primary and improved cultivars. The term clone was used to describe the cultivars of $H$. brasiliensis since propagation is by vegetative means [10]. Field germplasm of $H$. brasiliensis was maintained in source bush gardens, also called budwood gardens [11].

There was a total of seventy six clones of $H$. brasiliensis in the source bush gardens of the Rubber Research Institute of Nigeria from seven countries (Tables 1 and 2). The number of collections from Malaysia was the highest at fifty clones (Table 2). Other collections were ten, six, four, three, two and one from Indonesia, Nigeria, Sri Lanka, Brazil, Liberia and Vietnam respectively. The relatively high number of clones from Malaysia, Indonesia and Sri Lanka was due to early effort of research and development of natural rubber dating back to the 1890s, 1913 and 1926 in Indonesia, Sri Lanka and Malaysia respectively.

This genepool in Nigeria suggests that were some of these clones may have been lost in their countries of origin, Nigeria may provide such clones under relevant bilateral or multilateral arrangement. This is the advantage of duplicate gene pool as same genotypes conserved in various rubber producing countries can serve as back up in the event of loss of genotype as recommended by Normah et al. [12]. The six Nigerian clones have been registered with the relevant agencies in Nigeria [13]. Poor representation of germplasm of four countries viz Sri Lanka, Brazil, Liberia and Vietnam at less than five clones per country suggests improvement in germplasm exchange between Nigeria and these countries. It is noteworthy that Nigeria has no representation of clones from India and Thailand, which are among the first generation nations in the research, development and production of natural rubber from $\mathrm{H}$. brasiliensis [14]. This will be addressed in future.

Among the Hevea germplasm in Nigeria, 3\% consisted of clones of unknown status, $20 \%$ of primary clones and $76 \%$ for improved clones (Table 2). Clones of unknown status present a challenge as clarification may be obtained from the country of origin. The primary clones were rich sources of unexploited genes as they were selected from wild collections. The first set of improved clones was derived from crosses among the wild genotypes. For instance, RRIM 600 and RRIM 635 were selected from the cross between Tjir 1 and PB 86 that are primary clones (Table 1). The importance of the primary clones was also evident in many of the improved clones who have a parent as a primary clone. An example is PB 86, a primary clone which was a parent to a number of improved clones developed in Brazil and Malaysia. In Nigeria, three primary clones (Har 1, PR 107 and Tjir 1) were parents of improved clones (Table 1). The high number of improved clones at $76 \%$ was due to more than century gap between the earlier research effort of Malaysia, Sri Lanka, Indonesia, and Nigeria such that during introduction of germplasm in Nigeria in the 1960s, there was a pool of improved clones for collection [15]. 
Table 1 Clones of Hevea brasiliensis in Rubber Research Institute of Nigeria

\begin{tabular}{|c|c|c|c|}
\hline S/No & Clone & Origin & Parentage \\
\hline 1. & IAN 2880 & Brazil & Fx 516 x PB 86 \\
\hline 2. & IAN 2960 & Brazil & Fx 4073 x PB 86 \\
\hline 3. & IAN 2967 & Brazil & Unknown \\
\hline 4. & AV 49 & Indonesia & Primary clone \\
\hline 5. & AV 157 & Indonesia & Primary clone \\
\hline 6. & AV 275 & Indonesia & Primary clone \\
\hline 7. & AV 1581 & Indonesia & AV $214 \times$ AV 256 \\
\hline 8. & AV 1734 & Indonesia & AV 214 x AV 374 \\
\hline 9. & BR 2 & Indonesia & Primary clone \\
\hline 10. & GT 1 & Indonesia & Primary clone \\
\hline 11. & LCB1320 & Indonesia & Primary clone \\
\hline 12. & PR 107 & Indonesia & Primary clone \\
\hline 13. & Tjir 1 & Indonesia & Primary clone \\
\hline 14. & Har 1 & Liberia & Primary clone \\
\hline 15. & Har 2 & Liberia & Unknown \\
\hline 16. & CH 26 & Malaysia & BR $2 \times$ BR 2 \\
\hline 17. & CH 30 & Malaysia & BR $2 \times$ BR 2 \\
\hline 18. & RRIM 501 & Malaysia & Pil A 44 x Lun A 44 \\
\hline 19. & RRIM 509 & Malaysia & Pil A44 x Lun N \\
\hline 20. & RRIM 513 & Malaysia & PB 49 x Pil B 84 \\
\hline 21. & RRIM 519 & Malaysia & Pil A 44 x Pil B 16 \\
\hline 22. & RRIM 526 & Malaysia & Pil B 58 x Pil D 65 \\
\hline 23. & RRIM 527 & Malaysia & Pil B 50 x Pil B 84 \\
\hline 24. & RRIM 600 & Malaysia & Tjir 1 x PB 86 \\
\hline 25. & RRIM 602 & Malaysia & Tjir 1 x Gl 1 \\
\hline 26. & RRIM 603 & Malaysia & PB 86 x Pil B 84 \\
\hline 27. & RRIM 604 & Malaysia & Tjir 1 x PB 49 \\
\hline 28. & RRIM 605 & Malaysia & Tjir 1 x PB 49 \\
\hline 29. & RRIM 606 & Malaysia & Tjir 1 x PB 49 \\
\hline 30. & RRIM 607 & Malaysia & Tjir 1 x PB 49 \\
\hline 31. & RRIM 608 & Malaysia & AV 33 x Tjir 1 \\
\hline 32. & RRIM 609 & Malaysia & AVROS 157 x BD 5 \\
\hline 33. & RRIM 610 & Malaysia & RRIM 504 x Tjir 1 \\
\hline 34. & RRIM 611 & Malaysia & RRIM 504 x Tjir 1 \\
\hline 35. & RRIM 612 & Malaysia & AV 157 x PB 49 \\
\hline 36. & RRIM 613 & Malaysia & Tjir 1 x RRIM 509 \\
\hline 37. & RRIM 614 & Malaysia & Tjir 1 x RRIM 509 \\
\hline 38. & RRIM 616 & Malaysia & Tjir 1 x RRIM 507 \\
\hline
\end{tabular}




\begin{tabular}{|c|c|c|c|}
\hline 39. & RRIM 617 & Malaysia & BR 2 x RRIM 500 \\
\hline 40. & RRIM 619 & Malaysia & Tjir 1 x RRIM 501 \\
\hline 41. & RRIM 620 & Malaysia & RRIM 501 x RRIM 511 \\
\hline 42. & RRIM 621 & Malaysia & RRIM 504 x Tjir 1 \\
\hline 43. & RRIM 622 & Malaysia & Tjir 1 x Pil B 84 \\
\hline 44. & RRIM 624 & Malaysia & Tjir 1 x RRIM 529 \\
\hline 45. & RRIM 625 & Malaysia & Tjir 1 x RRIM 526 \\
\hline 46. & RRIM 627 & Malaysia & Tjir 1 x RRIM 526 \\
\hline 47. & RRIM 628 & Malaysia & Tjir 1 x RRIM 527 \\
\hline 48. & RRIM 630 & Malaysia & Tjir 1 x RRIM 527 \\
\hline 49. & RRIM 631 & Malaysia & RRIM 500 X Lun N \\
\hline 50. & RRIM 632 & Malaysia & Tjir 1 x PB 49 \\
\hline 51. & RRIM 634 & Malaysia & Tjir 1 x PB 186 \\
\hline 52. & RRIM 635 & Malaysia & Tjir 1 x PB 86 \\
\hline 53. & RRIM 636 & Malaysia & Pil B 84 x PB 86 \\
\hline 54. & RRIM 637 & Malaysia & PB 49 x Pil B84 \\
\hline 55. & RRIM 638 & Malaysia & RRIM $500 \times$ Lun N \\
\hline 56. & RRIM 707 & Malaysia & RRIM 632 x RRIM 501 \\
\hline 57. & PB 5/51 & Malaysia & PB 56 x PB 24 \\
\hline 58. & PB 5/63 & Malaysia & PB 56 x PB 24 \\
\hline 59. & PB 28/59 & Malaysia & Primary clone \\
\hline 60. & PB 23 & Malaysia & Primary clone \\
\hline 61. & PB 86 & Malaysia & Primary clone \\
\hline 62. & PB 213 & Malaysia & PB 56 x PB 86 \\
\hline 63. & PB 217 & Malaysia & PB 5/51 x PB 6/9 \\
\hline 64. & PILLA 44 & Malaysia & Primary clone \\
\hline 65. & FRIMSE & Malaysia & Unknown \\
\hline 66. & NIG 800 & Nigeria & RRIM 501 x Har 1 \\
\hline 67. & NIG 801 & Nigeria & RRIM $600 \times$ PR 107 \\
\hline 68. & NIG 802 & Nigeria & RRIM $501 \times$ RRIM 628 \\
\hline 69. & NIG 803 & Nigeria & RRIM 600 x PR 107 \\
\hline 70. & NIG 804 & Nigeria & RRIM 600 x Tjir 1 \\
\hline 71. & NIG 805 & Nigeria & RRIM $628 \times$ RRIM 501 \\
\hline 72. & NAB 15 & Sri Lanka & Tjikadoe seedling \\
\hline 73. & RRIC 45 & Sri Lanka & RRIC $8 \times$ Tjir 1 \\
\hline 74. & RRIC 75 & Sri Lanka & RRIC $8 \times$ Tjir 16 \\
\hline 75. & War 4 & Sri Lanka & Primary clone \\
\hline 76. & IRCI 7 & Vietnam & BD $10 \times$ BD 5 \\
\hline
\end{tabular}


Table 2 Country of origin of germplasm of Hevea brasiliensis in Rubber Research Institute of Nigeria

\begin{tabular}{|c|c|c|c|c|c|}
\hline \multirow{2}{*}{ S/No. } & \multirow{2}{*}{ Country } & \multirow{2}{*}{$\begin{array}{l}\text { Number of } \\
\text { clones* }\end{array}$} & \multicolumn{3}{|c|}{ Status } \\
\hline & & & Primary & Improved & Unknown \\
\hline 1. & Malaysia & $50 a$ & 4 & 45 & 1 \\
\hline 2. & Indonesia & $10 \mathrm{~b}$ & 8 & 2 & Nil \\
\hline 3. & Nigeria & $6 b$ & Nil & 6 & Nil \\
\hline 4. & Sri Lanka & $4 b$ & 2 & 2 & Nil \\
\hline 5. & Brazil & $3 b$ & Nil & 2 & 1 \\
\hline 6. & Liberia & $2 b$ & 1 & Nil & 1 \\
\hline \multirow[t]{2}{*}{7.} & Vietnam & $1 b$ & Nil & 1 & Nil \\
\hline & Total & 76 & $15(20 \%)$ & $58(76 \%)$ & $3(4 \%)$ \\
\hline
\end{tabular}

\section{Conclusion}

Nigeria has germplasm obtained from seven countries out of the first nine countries involved in development of the natural rubber industry world-wide. These included improved clones developed in Nigeria. The country, Nigeria is therefore in a position to feed new entrant-countries in improvement and cultivation of $H$. brasiliensis with germplasm. The available germplasm may also facilitate breeding for adaptation to climate change as breeding Hevea for adaptation to adverse conditions will require wide genetic variability.

\section{Compliance with ethical standards}

\section{Acknowledgments}

Authors are grateful to the Executive Director \& Management, Rubber Research Institute of Nigeria, Benin City for the support for this study. The assistance of technical staff in data collection is appreciated.

\section{Disclosure of conflict of interest}

The authors hereby declare that there is no conflict of interest.

\section{References}

[1] Venkatachalam P, Geetha N, Sangeetha P and Thulaseedharan A. (2013). Natural rubber producing plants: An overview. African Journal of Biotechnology, 12(12), 1297-1310.

[2] Priyadarshan PM, Goncalves PDS and Omokhafe KO. (2009). Breeding Hevea rubber. In: Jain SM, Priyadarshan PM. (Eds) Breeding Plantation Tree Crops. Tropical Species. Springer, New York, USA, 469-522.

[3] Datta RN. (2002) Rubber Curing Systems. Smithers Rapra Publishing, US, 150.

[4] IRRDB (2014). Minutes of meeting of IRRDB Plant Breeding Workshop. Rubber Research Institute of India, Kottayam, Kerala, India.

[5] Priyadarshan PM. (2003). Breeding Hevea brasiliensis for environmental constraints. Advances in Agronomy, $79,351-400$.

[6] Begho ER, Omokhafe KO, Omo-Ikerodah EE and Akpaja EO. (2007). Some observations on the fruit set and incidence of mistletoes on rubber trees in Nigeria. American-Eurasian Journal of Sustainable Agriculture, 1, 1318.

[7] RRIN (2009). RRIN in Brief. Rubber Research Institute of Nigeria, Benin City, Nigeria, 16. 
[8] Omokhafe KO and Imoren EA. (2014). The three NIG 800 series clones of Hevea brasiliensis for clone exchange under the International Rubber Research and Development Board. Meeting of Plant Breeding Group, International Rubber Research and Development Board, Kottayam, India, 5.

[9] Omokhafe KO and Nasiru I. (2005). Genetic improvement of Hevea brasiliensis in Nigeria. International Natural Rubber Conference, Cochin, India, 13-17.

[10] Omokhafe KO, Emuedo OA and Imoren EA. (2016). Intercharacter correlation between budding successes in Hevea brasiliensis Muell. Arg. and seven weather characters. International Journal of Plant and Soil Science, 11, $1-5$.

[11] Omokhafe KO, Oghide A and Imoren EA. (2015). Investment opportunities in the upstream sector of the natural rubber industry. Third Palm Oil, Rubber and Cocoa Conference, 13-15 October, 2015, Labadi Beach Hotel, Accra, Ghana. Organised by Centre for Management Technology, Singapore, 16.

[12] Normah MN, Chin HF and Barbara M. (Eds), Conservation of tropical plant species. Springer, New York, 2012, 538.

[13] NACGRAB (2013). Catalogue of crop varieties released and registered in Nigeria. National Centre for Genetic Resources and Biotechnology, Moor Plantation, Ibadan, Nigeria, 41.

[14] Tasie AO. (2015). Introduction to rubber materials and technology. Adyudo Press, Owerri, Nigeria, 154.

[15] Bassey E. (2014). Natural rubber development in Nigeria: challenges and prospects. In: Omokhafe KO, Bakare IO, Okore IK and Okwu UN (Eds), Proceedings of the first National Conference on Nigeria rubber industry. National Rubber Association of Nigeria, Benin City, Nigeria, 1-5.

\section{How to cite this article}

Omokhafe KO, Aghughu 0 and Imoren EA. (2017). Germplasm of Hevea brasiliensis in Nigeria. GSC Biological and Pharmaceutical Sciences, 1(2), 20-25. 